\title{
THE INFLUENCE OF CLOTHING, WORK, AND AIR MOVEMENT ON THE THERMAL EXCHANGES OF ACCLIMATIZED MEN IN VARIOUS HOT ENVIRONMENTS
}

\author{
By NORTON A. NELSON, ${ }^{1}$ WALTER B. SHELLEY, ${ }^{2}$ STEVEN M. HORVATH, ${ }^{2}$ \\ LUDWIG W. EICHNA, ${ }^{1}$ AND THEODORE F. HATCH ${ }^{3}$ \\ (From the Armored Medical Research Laboratory, Fort Knox, Kentucky)
}

(Received for publication August 11, 1947)

During the war the need for the study of the mechanism of heat loss at high temperatures became evident. Although extensive calorimetric studies of man's thermal exchanges under certain environmental conditions have been made, quantitative calorimetric data on men in very hot environments have been missing $(1,2)$. Technical difficulties essentially preclude the possibility of using direct calorimetry to secure such information. However, the partitional calorimetric approach of the Pierce Laboratory (3) does allow a quantitative description of thermal exchanges in these hot environments which hitherto were considered largely in terms of qualitative patterns. In the present work, such a partitional calorimetric study was made of men in the heat to extend the measurements of environmental load factors and to describe man's responses to high environmental temperatures. This communication gives the basic calorimetric and physiological data obtained and indicates the effects of clothing, work, and air movement on the routes of thermal interchange in a series of hot environments. The data, although not as exact as may be desired, may therefore be useful.

\section{PROCEDURE}

Partitional calorimetric studies were made on four well-acclimatized, healthy young male subjects, whose ages ranged from 20 to 22 years; heights, from 166 to $185 \mathrm{~cm}$.; weights, from 62 to $74 \mathrm{kgm}$.; and surface areas from 1.7 to $1.9 \mathrm{~m}^{2}$. Acclimatization was achieved by having the subjects, dressed in herringbone twill uniforms, walk daily for a period of four hours in an environment having dry bulb temperatures (D.B.) of $120^{\circ} \mathrm{F}$. and wet bulb temperatures (W.B.) of $88^{\circ} \mathrm{F}$.

\footnotetext{
1 New York University.

2 University of Pennsylvania Graduate School of Medicine.

3 Industrial Hygiene Foundation of America, Pittsburgh, Penna.
}

Following acclimatization, calorimetric investigations were made on these men. The fourth, or reserve subject replaced subject no. 3 after the eleventh day of the test.

The tests were conducted in a laboratory hot room within a black sheet metal wind tunnel which measured $51 / 2 \mathrm{ft}$. by $71 / 2 \mathrm{ft}$. by $20 \mathrm{ft}$. The dry and wet bulb temperatures were maintained to within $1^{\circ} \mathrm{F}$. of the stated values. Six 24-inch fans at the discharge end of the tunnel produced linear air flow, controlled by louvres and/or fan speed. Eight-inch galvanized pipes served as air straighteners at the inflow end. The men stood or walked on the treadmill which constituted the central portion of the tunnel floor. A speed of 3 m.p.h. and a grade of 3.0 per cent were employed in the walking tests, resulting in an average energy expenditure of 160 $\mathrm{Cal} . / \mathrm{m}^{2} / \mathrm{hr}$. Energy expenditures during standing averaged $55 \mathrm{Cal} . / \mathrm{m}^{2} / \mathrm{hr}$.

The seven environments and the five wind velocities employed are given in Table I. Each of the three men was studied standing nude, standing clothed, and walking clothed once in each of the 35 hot environmental conditions. Exposure to the environments was randomized so that severe and less severe stress periods were well interspersed with each other. The test periods were 30 minutes long. Difficulties in preventing loss of unevaporated sweat precluded experiments on the nude walking man. Throughout the study, observations were repeated in a "base" environment (D.B. $120^{\circ}$ F., W.B. $88^{\circ}$ F., wind velocity $300 \mathrm{ft} . / \mathrm{min}$.) on days $1,10,20,29,38$, and 47 , to obtain information regarding the constancy of response of the subjects to a given environment (Figure 1).

The men spent $71 / 2$ hours in the heat each day except Sunday. In the morning, after marching for 70 minutes in the hot room for equilibration, the test run was made

TABLE I

Environments in which men were studied

\begin{tabular}{c|c|c|c|c}
\hline \hline & $\begin{array}{c}\text { Dry bulb } \\
\text { temp. }\end{array}$ & $\begin{array}{c}\text { Wet bulb } \\
\text { temp. }\end{array}$ & $\begin{array}{c}\text { Relative } \\
\text { humidity }\end{array}$ & Wind velocity \\
\cline { 2 - 4 } & $\begin{array}{c}\text { degrees } F \\
1\end{array}$ & 90 & $\begin{array}{c}\text { degrees } F . \\
\text { per cent }\end{array}$ & $\begin{array}{c}\text { feet } / \text { min. (approx.) } \\
2\end{array}$ \\
96 & 72 & 37 & $30,75,150,300,600$ \\
3 & 96 & 83 & 31 & $30,75,150,300,600$ \\
4 & 96 & 91 & 83 & $30,75,150,300,600$ \\
5 & 105 & 74 & 23 & $30,75,150,300,600$ \\
6 & 120 & 78 & 12 & $30,75,150,300,600$ \\
7 & 120 & 88 & 28 & $30,75,150,300,600$ \\
\hline
\end{tabular}




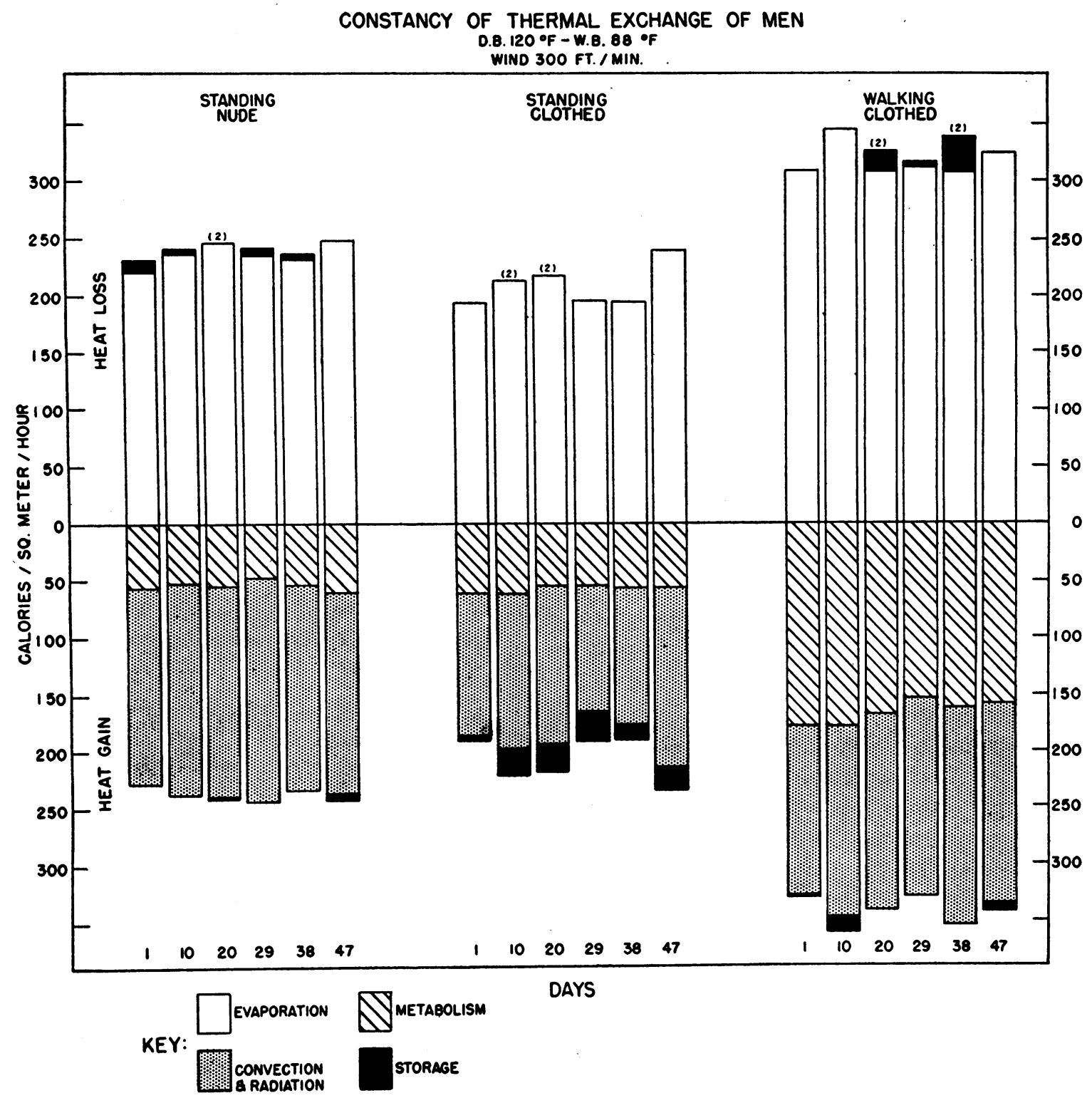

Fig. 1. Constancy of Thermal Exchanges of Men Studied Periodically During Two Months, with a Comparison of the Nude, Clothed and Work State

All studies carried out at D.B. $120^{\circ}$ F.-W.B. $88^{\circ}$ F. in a wind of $300 \mathrm{ft} . / \mathrm{min}$. Data are average of three men.

on the walking man. In the afternoon, experiments were done on the men standing nude or clothed. Each of these tests was preceded by a special equilibrating stand of 20 minutes.

During the clothed experiments the subjects wore well-laundered two-piece herringbone twill fatigue uniforms, light wollen socks, cotton shorts and field shoes. A completely dry outfit was donned prior to the start of the test period. Sweat losses from drippage were found to be insignificant. In nude trials, the men stood over shallow trays containing mineral oil to collect un- evaporated sweat. Water salted to 0.1 per cent was given in amounts approximating sweat loss just before the test period, and at midpoint in the walking experiments.

Table II presents the types of data collected during each experiment. A detailed account of the procedures, theoretical basis for and treatment of those data has been published (4). Briefly, the collected data are converted into quantitative expressions of thermal exchange by utilization of the basic thermal exchange equation: $M+E \pm S \pm C \pm R=0$ where the symbol 
$M=$ rate of metabolic heat production,

$\mathrm{S}=$ rate of change in body heat content or storage,

$\mathrm{E}=$ rate of evaporative heat loss,

$C=$ rate of thermal exchange by convection, and

$R=$ rate of thermal exchange by radiation.

$\mathrm{M}$ and $\mathrm{E}$ were measured directly, $\mathrm{S}$ was calculated from the skin and rectal temperature changes, while $C+R$ were determined by difference as defined in the above equation. No attempt has been made in this overall treatment to separate convective and radiant heat exchange; one method for such separation has been applied to these data (4). All figures are expressed as Cal./ $\mathrm{m}^{2} / \mathrm{hr}$.

\section{RESULTS AND DISCUSSION}

Table III affords a survey of the average responses of the three men under differing conditions of activity and environment. Only the extremes of wind velocity are represented in the table, but it can be seen from Figures 2 to 4 that the intermediate data are in an orderly sequence. At any given air velocity, increasing the work, in-

TABLE II

Experimental data collected during each test period

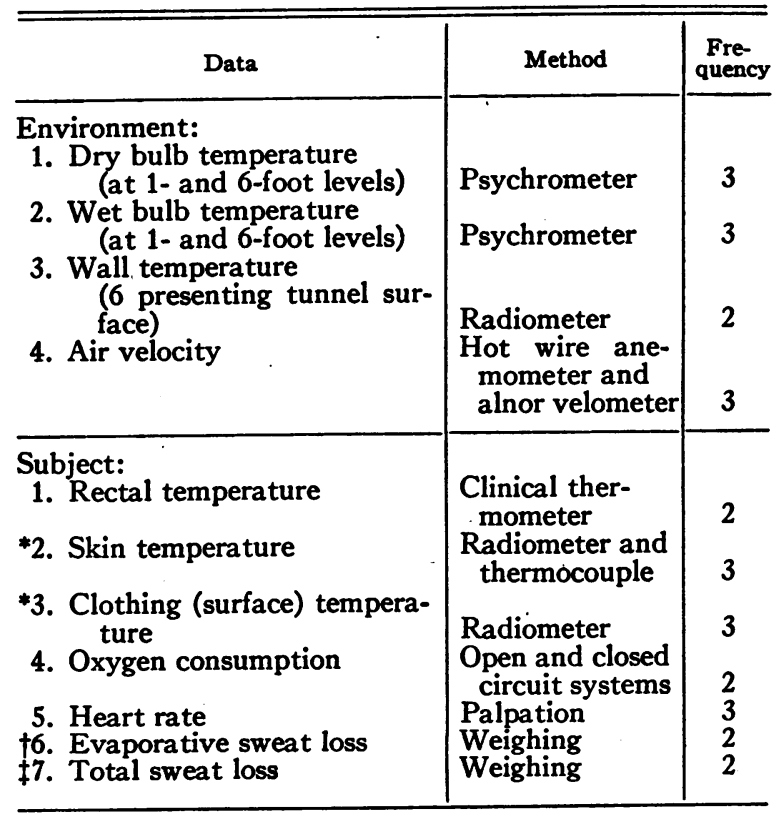

* Integration of six areas, viz., Cheek, Chest, Back or Calf, Palm, Thigh and Upper Arm.

$\dagger$ Total sweat loss minus weight of sweat dripped and toweled off body.

$\ddagger$ Change in weight of nude subject with correction for water consumed and excess weight of $\mathrm{CO}_{2}$ excreted over $\mathrm{O}_{2}$ consumed. creasing the heat load or wearing clothing led to elevations in the sweating rate, heart rate, rectal and skin temperatures.

Analysis of Table III reveals that in the conditions studied, increasing the wind velocity from 30 to 600 feet per minute did not produce any striking change in the rectal temperature. In no case was the average rectal temperature changed $1^{\circ} \mathrm{F}$. However, such an increase in air temperature was generally associated with significant reductions in the skin temperatures of the subjects, whether nude or clothed, standing or marching. Surface temperatures in clothed men followed this pattern of the skin temperatures at environments in which the temperature did not exceed $96^{\circ} \mathrm{F}$. In the $105^{\circ}$ and $120^{\circ}$ environments the surface temperature rose with increasing air movement, occasionally attaining values above $105^{\circ} \mathrm{F}$. Total sweat loss was most strikingly reduced by an increase in wind velocity in the tests at $120^{\circ}$ on clothed subjects. Appreciable pulse rate reductions occurred with an increase in air velocity, in clothed men working at wet bulb temperatures of $88^{\circ}$ or $91^{\circ}$.

The results of the partitional calorimetric analysis are given in block form in Figures 1 to 4 . The ordinate represents heat exchange in Cal./ $\mathrm{m}^{2} / \mathrm{hr}$.; heat loss being represented above and heat gain below the dividing line. Along the abscissa the environments are presented, with each group of blocks showing the effect of five progressively increasing air velocities for a given dry and wet bulb temperature. The results on nude, clothed and working men are presented in individual charts. The data are the averages of three men except where the numeral (2) appears indicating that the averages are for two men.

Figure 1 shows the degree of constancy in the physiological thermoregulatory mechanisms, since it presents data on men reexposed to exactly the same environment on six different days over a two-month period. These data serve as an aid in evaluation of the significance of changes seen in the other charts.

Metabolic heat production for a given amount of work remains unchanged irrespective of change in environmental conditions. Convective and ra- 
TABLE III

Effect of environment, activity and clothing on physiological responses of acclimatized men Average data on three men during half-hour exposure

\begin{tabular}{|c|c|c|c|c|c|c|c|c|c|c|c|c|c|}
\hline \multirow{2}{*}{ Environment } & \multirow{2}{*}{$\begin{array}{c}\text { Wind } \\
\text { velocity }\end{array}$} & \multirow{2}{*}{ Activity } & \multirow{2}{*}{ Clothing } & \multicolumn{2}{|c|}{$\begin{array}{c}\text { Rectal } \\
\text { temperature }\end{array}$} & \multicolumn{2}{|c|}{$\begin{array}{c}\text { Skin } \\
\text { temperature }\end{array}$} & \multicolumn{2}{|c|}{$\begin{array}{l}\text { Surface } \\
\text { temperature }\end{array}$} & \multicolumn{2}{|r|}{ Sweat } & \multicolumn{2}{|c|}{$\begin{array}{l}\text { Pulse rate } \\
\text { (minutes) }\end{array}$} \\
\hline & & & & Final & Change & Final & Change & Final & Change & Total & Evaporation & Final & Change \\
\hline D. B. $90^{\circ} \mathrm{F}$. & $\begin{array}{c}f i . / \min . \\
30\end{array}$ & $\begin{array}{l}\text { Standing } \\
\text { Standing } \\
\text { Walking }\end{array}$ & $\begin{array}{l}0 \\
+ \\
+\end{array}$ & $\begin{array}{l}98.9 \\
99.2 \\
99.4\end{array}$ & $\begin{array}{r}0.2 \\
0.3 \\
-0.1\end{array}$ & $\begin{array}{l}93.3 \\
93.6 \\
93.0\end{array}$ & $\begin{array}{l}-1.0 \\
-0.7 \\
-0.9\end{array}$ & $\begin{array}{l}\overline{94.8} \\
93.6\end{array}$ & $\begin{array}{l}\overline{-} \\
-0.2 \\
-0.8\end{array}$ & $\begin{array}{r}\text { gm./hr. } \\
158 \\
208 \\
603\end{array}$ & $\begin{array}{c}\text { per cent } \\
98 \\
66 \\
60\end{array}$ & $\begin{array}{r}82 \\
90 \\
106\end{array}$ & $\begin{array}{l}1 \\
2 \\
4\end{array}$ \\
\hline W. B. $70^{\circ} \mathrm{F}$. & 600 & $\begin{array}{l}\text { Standing } \\
\text { Standing } \\
\text { Walking }\end{array}$ & $\begin{array}{l}0 \\
+ \\
+\end{array}$ & $\begin{array}{l}98.8 \\
99.0 \\
99.2\end{array}$ & $\begin{array}{r}0.2 \\
0.0 \\
-0.1\end{array}$ & $\begin{array}{l}92.0 \\
91.4 \\
90.8\end{array}$ & $\begin{array}{l}-1.4 \\
-1.1 \\
-1.2\end{array}$ & $\begin{array}{l}\overline{93.6} \\
91.6\end{array}$ & $\begin{array}{r}\overline{0.2} \\
-0.9\end{array}$ & $\begin{array}{l}152 \\
183 \\
564\end{array}$ & $\begin{array}{r}100 \\
88 \\
73\end{array}$ & $\begin{array}{l}79 \\
85 \\
97\end{array}$ & $\begin{array}{r}-2 \\
0 \\
-4\end{array}$ \\
\hline D. B. $96^{\circ} \mathrm{F}$. & 30 & $\begin{array}{l}\text { Standing } \\
\text { Standing } \\
\text { Walking }\end{array}$ & $\begin{array}{l}0 \\
+ \\
+\end{array}$ & $\begin{array}{l}99.0 \\
99.1 \\
99.3\end{array}$ & $\begin{array}{r}0.3 \\
0.3 \\
-0.1\end{array}$ & $\begin{array}{l}93.8 \\
93.7 \\
92.1\end{array}$ & $\begin{array}{l}-1.1 \\
-2.0 \\
-2.4\end{array}$ & $\begin{array}{l}\overline{96.8} \\
93.8\end{array}$ & $\begin{array}{l}\overline{-1.6} \\
-1.8\end{array}$ & $\begin{array}{r}262 \\
395 \\
1019\end{array}$ & $\begin{array}{l}94 \\
56 \\
50\end{array}$ & 75 & $\begin{array}{r}-2 \\
3 \\
0\end{array}$ \\
\hline W. B. $72^{\circ} \mathrm{F}$. & 600 & $\begin{array}{l}\text { Standing } \\
\text { Standing } \\
\text { Walking }\end{array}$ & $\begin{array}{l}0 \\
+ \\
+\end{array}$ & $\begin{array}{l}99.4 \\
99.6 \\
99.6\end{array}$ & $\begin{array}{r}0.3 \\
0.4 \\
-0.2\end{array}$ & $\begin{array}{l}93.4 \\
92.7 \\
92.1\end{array}$ & $\begin{array}{l}-1.3 \\
-1.7 \\
-1.2\end{array}$ & $\begin{array}{l}\overline{96.0} \\
94.6\end{array}$ & $\begin{array}{l}\overline{-0} \\
-0.5 \\
-0.8\end{array}$ & $\begin{array}{l}279 \\
278 \\
670\end{array}$ & $\begin{array}{l}99 \\
86 \\
74\end{array}$ & $\begin{array}{l}103 \\
103 \\
105\end{array}$ & $\begin{array}{l}9 \\
2 \\
3\end{array}$ \\
\hline D. B. $96^{\circ} \mathrm{F}$. & 30 & $\begin{array}{l}\text { Standing } \\
\text { Standing } \\
\text { Walking }\end{array}$ & $\begin{array}{l}0 \\
+ \\
+\end{array}$ & $\begin{array}{r}99.4 \\
99.7 \\
100.1\end{array}$ & $\begin{array}{l}0.3 \\
0.4 \\
0.4\end{array}$ & $\begin{array}{l}94.6 \\
95.2 \\
95.6\end{array}$ & $\begin{array}{l}-0.6 \\
-0.8 \\
-0.5\end{array}$ & $\begin{array}{l}\overline{95.6} \\
96.0\end{array}$ & $\begin{array}{r}-\overline{1.5} \\
0.0\end{array}$ & $\begin{array}{r}316 \\
815 \\
1666\end{array}$ & $\begin{array}{l}70 \\
24 \\
26\end{array}$ & $\begin{array}{r}93 \\
100 \\
108\end{array}$ & $\begin{array}{r}1 \\
4 \\
-3\end{array}$ \\
\hline W. B. $83^{\circ} \mathrm{F}$. & 600 & $\begin{array}{l}\text { Standing } \\
\text { Standing } \\
\text { Walking }\end{array}$ & $\begin{array}{l}0 \\
+ \\
+\end{array}$ & $\begin{array}{l}99.0 \\
99.0 \\
99.5\end{array}$ & $\begin{array}{l}0.2 \\
0.2 \\
0.1\end{array}$ & $\begin{array}{l}93.0 \\
93.2 \\
93.8\end{array}$ & $\begin{array}{l}-0.3 \\
-2.3 \\
-2.8\end{array}$ & $\begin{array}{l}\overline{94.9} \\
92.9\end{array}$ & $\begin{array}{l}\overline{-} \\
-0.3 \\
-1.3\end{array}$ & $\begin{array}{r}292 \\
433 \\
1397\end{array}$ & $\begin{array}{r}100 \\
69 \\
49\end{array}$ & $\begin{array}{r}82 \\
73 \\
103\end{array}$ & $\begin{array}{r}7 \\
-10 \\
10\end{array}$ \\
\hline D. B. $96^{\circ} \mathrm{F}$. & 30 & & $\begin{array}{l}0 \\
+ \\
+\end{array}$ & $\begin{array}{r}99.7 \\
99.9 \\
102.4\end{array}$ & $\begin{array}{l}0.3 \\
0.3 \\
1.6\end{array}$ & $\begin{array}{l}96.5 \\
96.3 \\
98.6\end{array}$ & $\begin{array}{r}-0.1 \\
0.4 \\
0.2\end{array}$ & $\begin{array}{l}\overline{96.7} \\
98.5\end{array}$ & $\begin{array}{r}\overline{0.1} \\
-0.5\end{array}$ & $\begin{array}{r}815 \\
1270 \\
2357\end{array}$ & $\begin{array}{l}17 \\
12 \\
13\end{array}$ & $\begin{array}{r}97 \\
102 \\
159\end{array}$ & $\begin{array}{r}7 \\
12 \\
18\end{array}$ \\
\hline W. B. $91^{\circ} \mathrm{F}$. & 600 & $\begin{array}{l}\text { Standing } \\
\text { Standing } \\
\text { Walking }\end{array}$ & $\begin{array}{l}0 \\
+ \\
+\end{array}$ & $\begin{array}{r}99.6 \\
99.7 \\
101.7\end{array}$ & $\begin{array}{l}0.2 \\
0.3 \\
0.8\end{array}$ & $\begin{array}{l}94.1 \\
94.6 \\
97.3\end{array}$ & $\begin{array}{l}-0.3 \\
-1.6 \\
-0.4\end{array}$ & $\begin{array}{l}\overline{94.0} \\
95.9\end{array}$ & $\begin{array}{l}\overline{-1.2} \\
-0.7\end{array}$ & $\begin{array}{r}351 \\
814 \\
2275\end{array}$ & $\begin{array}{l}77 \\
34 \\
24\end{array}$ & $\begin{array}{l}102 \\
106 \\
137\end{array}$ & $\begin{array}{r}2 \\
-4 \\
15\end{array}$ \\
\hline D. B. $105^{\circ} \mathrm{F}$. & 30 & $\begin{array}{l}\text { Standing } \\
\text { Standing } \\
\text { Walking }\end{array}$ & $\begin{array}{l}0 \\
+ \\
+\end{array}$ & $\begin{array}{l}99.7 \\
99.7 \\
99.4\end{array}$ & $\begin{array}{r}0.7 \\
0.5 \\
-0.1\end{array}$ & $\begin{array}{l}93.4 \\
93.5 \\
94.1\end{array}$ & $\begin{array}{l}-1.0 \\
-3.9 \\
-2.0\end{array}$ & $\begin{array}{l}\overline{97.6} \\
95.7\end{array}$ & $\begin{array}{l}\overline{-4.2} \\
-3.4\end{array}$ & $\begin{array}{r}388 \\
684 \\
1179\end{array}$ & $\begin{array}{l}92 \\
41 \\
47\end{array}$ & $\begin{array}{r}91 \\
95 \\
104\end{array}$ & $\begin{array}{r}2 \\
1 \\
-7\end{array}$ \\
\hline W. B. $74^{\circ} \mathrm{F}$. & 600 & $\begin{array}{l}\text { Standing } \\
\text { Standing } \\
\text { Walking }\end{array}$ & $\begin{array}{l}0 \\
+ \\
+\end{array}$ & & $\begin{array}{l}0.4 \\
0.3 \\
0.2\end{array}$ & $\begin{array}{l}92.8 \\
91.9 \\
93.3\end{array}$ & $\begin{array}{l}-1.7 \\
-3.6 \\
-2.4\end{array}$ & $\begin{array}{r}\overline{101.3} \\
96.8\end{array}$ & $\begin{array}{r}\overline{0.9} \\
-1.0\end{array}$ & $\begin{array}{r}534 \\
478 \\
1027\end{array}$ & $\begin{array}{l}99 \\
78 \\
72\end{array}$ & $\begin{array}{r}84 \\
81 \\
102\end{array}$ & $\begin{array}{r}3 \\
-3 \\
-2\end{array}$ \\
\hline D. B. $120^{\circ} \mathrm{F}$. & 30 & $\begin{array}{l}\text { Standing } \\
\text { Standing } \\
\text { Walking }\end{array}$ & $\begin{array}{l}0 \\
+ \\
+\end{array}$ & & $\begin{array}{l}0.3 \\
0.4 \\
0.4\end{array}$ & $\begin{array}{l}95.9 \\
96.3 \\
96.6\end{array}$ & $\begin{array}{l}-1.3 \\
-2.7 \\
-2.2\end{array}$ & $\begin{array}{r}1 \overline{00.6} \\
99.9\end{array}$ & $\begin{array}{l}\overline{-6.1} \\
-4.5\end{array}$ & $\begin{array}{r}573 \\
1379 \\
1883\end{array}$ & $\begin{array}{l}86 \\
28 \\
37\end{array}$ & $\begin{array}{r}90 \\
102 \\
111\end{array}$ & $\begin{array}{r}0 \\
6 \\
-3\end{array}$ \\
\hline W. B. $78^{\circ} \mathrm{F}$. & 600 & $\begin{array}{l}\text { Standing } \\
\text { Standing } \\
\text { Walking }\end{array}$ & $\begin{array}{l}0 \\
+ \\
+\end{array}$ & $\begin{array}{r}100.1 \\
100.0 \\
99.8\end{array}$ & $\begin{array}{l}0.7 \\
0.3 \\
0.1\end{array}$ & $\begin{array}{l}95.1 \\
94.0 \\
95.3\end{array}$ & $\begin{array}{l}-0.4 \\
-5.3 \\
-4.1\end{array}$ & $\begin{array}{l}\overline{107.3} \\
104.5\end{array}$ & $\begin{array}{l}\overline{-1.7} \\
-0.9\end{array}$ & $\begin{array}{r}815 \\
850 \\
1345\end{array}$ & $\begin{array}{l}99 \\
71 \\
69\end{array}$ & $\begin{array}{l}115 \\
107 \\
106\end{array}$ & $\begin{array}{r}9 \\
1 \\
-11\end{array}$ \\
\hline D. B. $120^{\circ} \mathrm{F}$ & 30 & $\begin{array}{l}\text { Standing } \\
\text { Standing } \\
\text { Walking }\end{array}$ & $\begin{array}{l}0 \\
+ \\
+\end{array}$ & $\begin{array}{l}100.4 \\
101.1 \\
102.2\end{array}$ & $\begin{array}{l}0.6 \\
1.0 \\
1.7\end{array}$ & $\begin{array}{r}98.7 \\
98.6 \\
100.0\end{array}$ & $\begin{array}{r}0.3 \\
-1.6 \\
-0.2\end{array}$ & $\begin{array}{l}100.6 \\
100.6\end{array}$ & $\begin{array}{l}\overline{-2.2} \\
-2.4\end{array}$ & $\begin{array}{l}1351 \\
2000 \\
2650\end{array}$ & $\begin{array}{l}27 \\
18 \\
25\end{array}$ & $\begin{array}{l}125 \\
142 \\
171\end{array}$ & $\begin{array}{r}9 \\
16 \\
32\end{array}$ \\
\hline W. B. $88^{\circ} \mathrm{F}$. & 600 & $\begin{array}{l}\text { Standing } \\
\text { Standing } \\
\text { Walking }\end{array}$ & $\begin{array}{l}0 \\
+ \\
+\end{array}$ & $\begin{array}{l}100.2 \\
100.2 \\
101.5\end{array}$ & $\begin{array}{l}0.4 \\
0.5 \\
1.0\end{array}$ & $\begin{array}{l}96.6 \\
96.7 \\
97.9\end{array}$ & $\begin{array}{l}-0.7 \\
-4.0 \\
-0.9\end{array}$ & $\begin{array}{l}\overline{105.2} \\
101.9\end{array}$ & $\begin{array}{l}-\overline{1.5} \\
-2.3\end{array}$ & $\begin{array}{r}884 \\
1197 \\
2046\end{array}$ & $\begin{array}{l}97 \\
57 \\
52\end{array}$ & $\begin{array}{l}111 \\
115 \\
134\end{array}$ & $\begin{array}{r}3 \\
4 \\
14\end{array}$ \\
\hline
\end{tabular}

Data on intermediate wind velocities not given.

diant heat gain, and the compensatory evaporative heat loss in the warmer environments show a progressive increase as the air movement is increased.
The equilibration period preceding the test period served in most instances to keep storage heat at a low level. Clothing on resting men resulted 


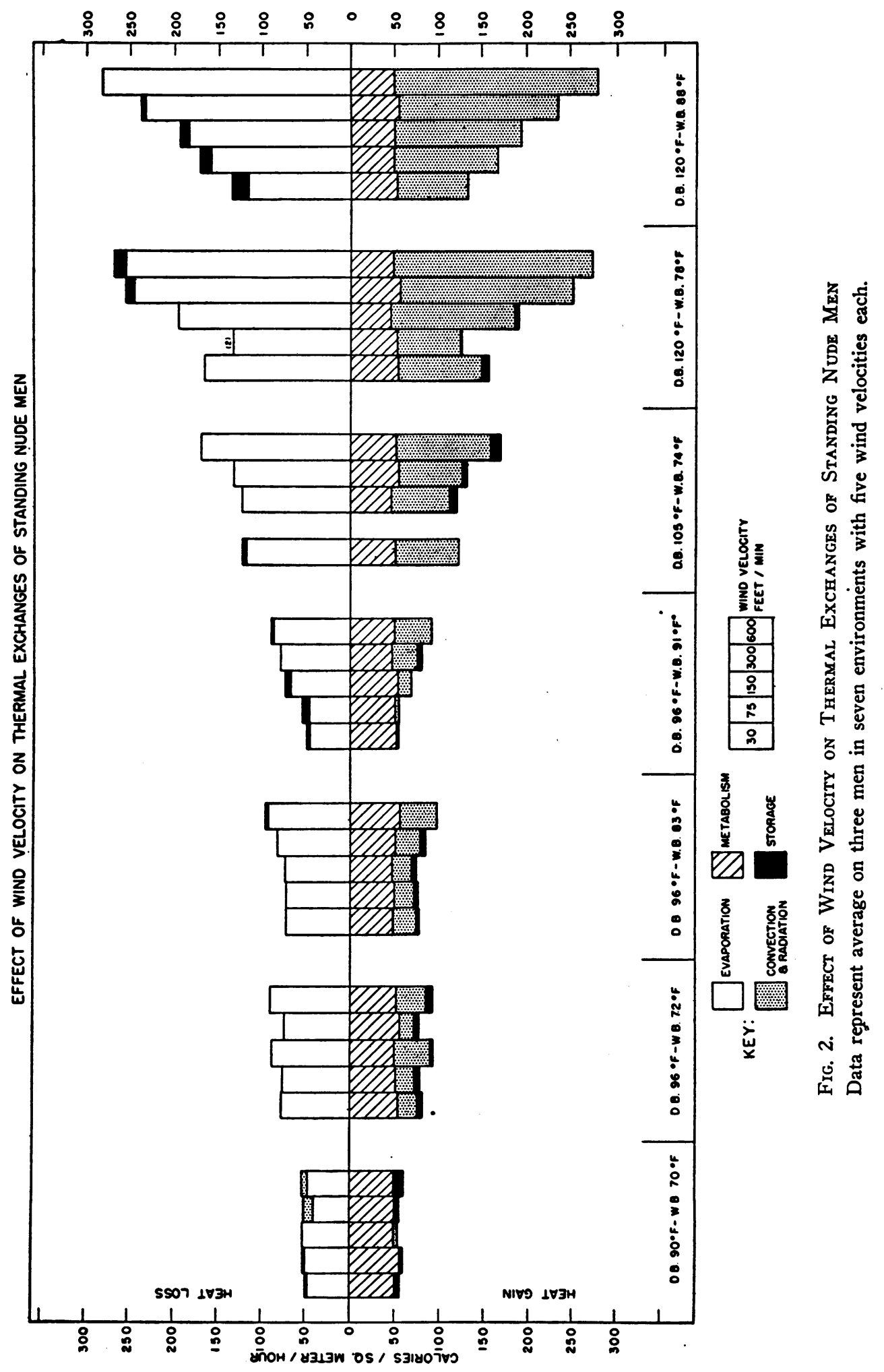




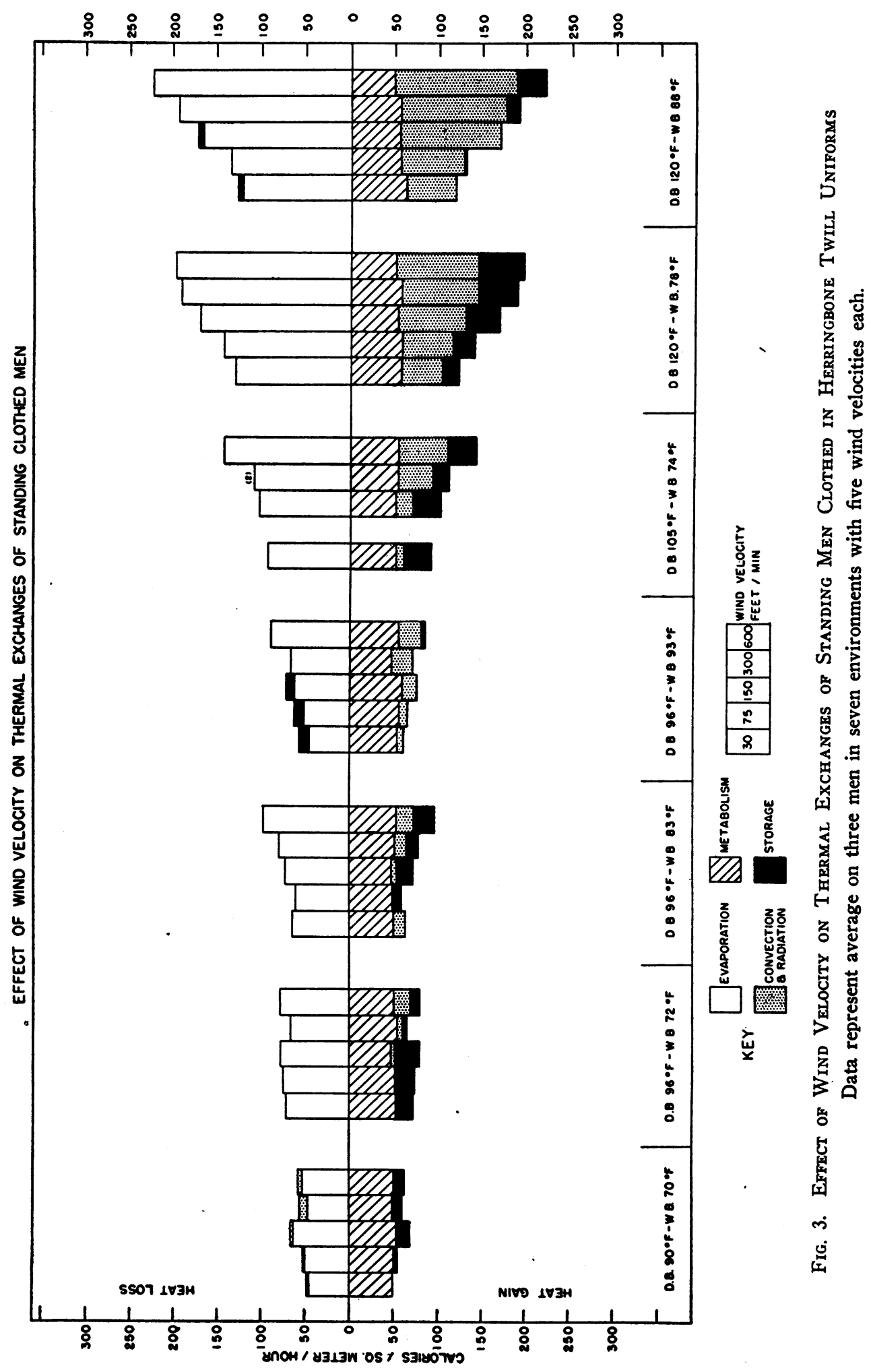




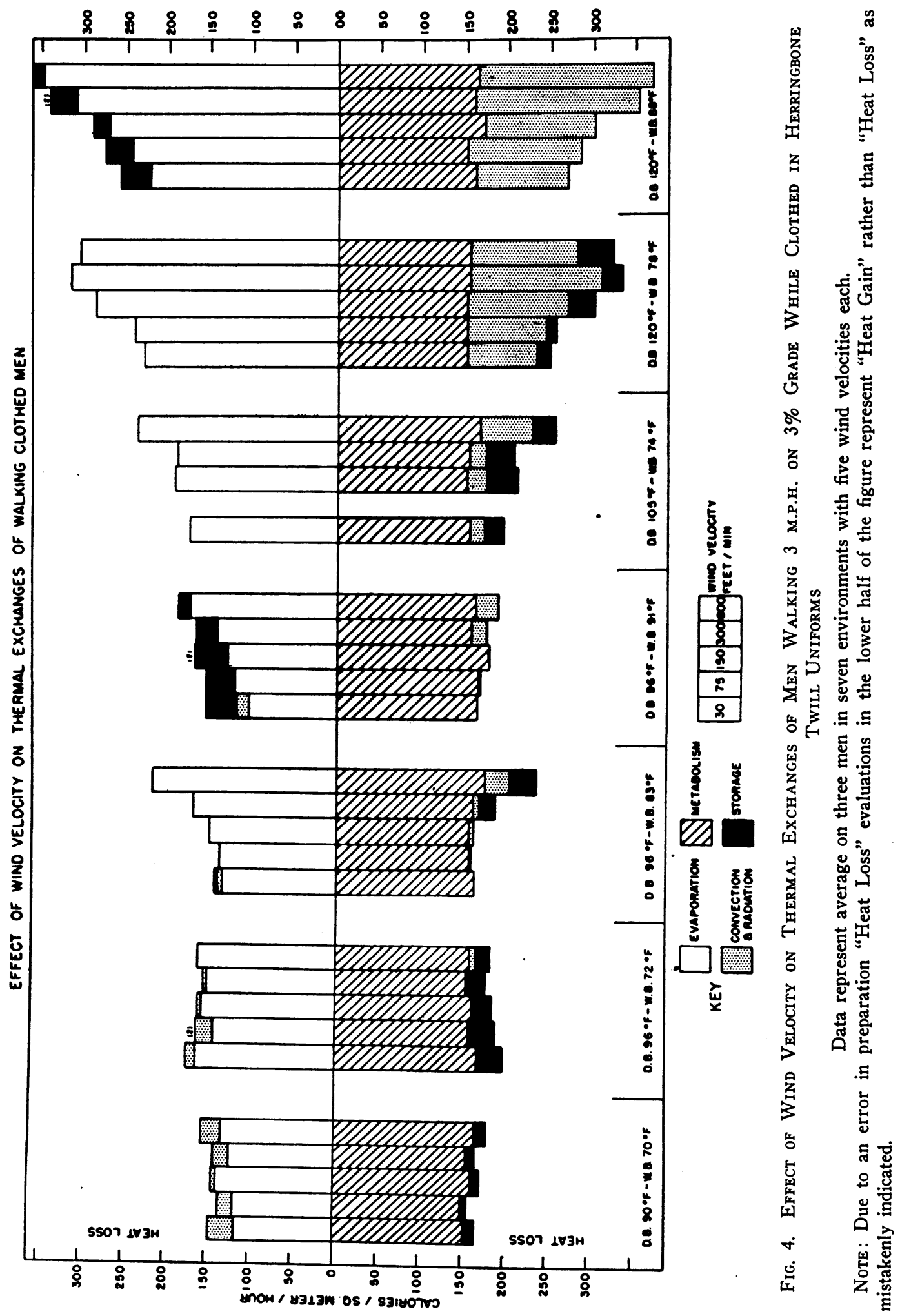


in smaller heat gains by convection and radiation and consequently in a smaller evaporative heat loss.

\section{SUM MARY}

Partitional calorimetric data and their physiologic correlates have been presented to show the thermal exchanges and responses of three acclimatized men, nude and clothed, while standing and walking in a series of seven hot environments $\left(90^{\circ}\right.$ to $120^{\circ}$ F.). In each of the environments the effects of varying the wind velocity between 30 and 600 feet per minute were determined. Convective and radiant heat gain and the compensatory evaporative heat loss showed a progressive increase with increasing air movement.

\section{BIBLIOGRAPHY}

1. Hardy, J. D., and DuBois, E. F., Basal metabolism, radiation, convection, and vaporization at temperatures of 22 to $33^{\circ}$ C. J. Nutrition, 1938, 15, 477.

2. Winslow, C. E. A., Herrington, L. P., and Gagge, A. P., Physiological reactions of the human body to varying environmental temperatures. Am. J. Physiol., 1937, 120, 1.

3. Winslow, C. E. A., Gagge, A.P., and Herrington, L. P., Heat exchanges and regulation in radiant environments above and below air temperature. Am. J. Physiol., 1940, 131, 79.

4. Nelson, N. A., Eichna, L. W., Horvath, S. M., Shelley, W. B., and Hatch, T. F., Thermal exchanges of man at high temperatures. Am. J. Physiol., 1947, $151,626$.

5. Winslow, C. E. A., Herrington, L. P., and Gagge, A. P., A new method of partitional calorimetry. Am. J. Physiol., 1936, 116, 641. 